\title{
The life, achievements and legacy of a great Canadian investigator: Professor Boris Petrovich Babkin (1877-1950)
}

\author{
Ivan T Beck MD PhD FRCPC FACP MACG
}

\begin{abstract}
IT Beck. The life, achievements and legacy of a great Canadian investigator: Professor Boris Petrovich Babkin (1877-1950). Can J Gastroenterol 2006;20(9):579-588.
\end{abstract}

The present paper reviews the life and achievements of Professor Boris Petrovich Babkin (MD DSc LLD). History is only worth writing about if it teaches us about the future; therefore, this historical review concludes by describing what today's and future gastrointestinal physiologists could learn from Dr Babkin's life.

Dr Babkin was born in Russia in 1877. He graduated with an MD degree from the Military Medical Academy in St Petersburg, Russia, in 1904. Not being attracted to clinical practice, and after some hesitation concerning whether he would continue in history or basic science of medicine, he entered the laboratory of Professor Ivan Petrovich Pavlov. Although he maintained an interest in history, in Pavlov's exciting environment he became fully committed to physiology of the gastrointestinal system. He advanced quickly in Russia and was Professor of Physiology at the University of Odessa. In 1922, he was critical of the Bolshevik revolution, and after a short imprisonment, he was ordered to leave Russia. He was invited with his family by Professor EH Starling (the discoverer of secretin) to his department at University College, London, England. Two years later, he was offered a professorship in Canada at Dalhousie University, Halifax, Nova Scotia. After contributing there for four years, he joined McGill University, Montreal, Quebec, in 1928 as Research Professor. He remained there for the rest of his career. Between 1940 and 1941, he chaired the Department, and following retirement, he remained as Research Professor. At the invitation of the world-famous neurosurgeon, Wilder Penfield, Dr Babkin continued as Research Fellow in the Department of Neurosurgery until his death in 1950 at age 73.

His major achievements were related to establishing the concept of brain-gut-brain interaction and the influence of this on motility, as well as on interface of multiple different cells, nerves and hormones on secretory function. He had a major role in the rediscovery of gastrin. He established a famous school of gastrointestinal physiologists at McGill University. He supported his trainees and helped them establish their careers. He received many honors: a DSc in London, England, and an LLD from Dalhousie University. Most importantly, he was the recipient of the Friedenwald Medal of the American Gastroenterological Association for lifelong contributions to the field. Dr Babkin taught us his philosophical aspect of approaching physiology, his devotion to his disciples and his overall kindness. Most importantly, he has proven that one can achieve international recognition by publishing mainly in Canadian journals. He is an example to follow.

Key Words: Biography; Boris Petrovich Babkin; Brain-gut-brain interaction; Friedenwald Medal; Gastrin; GI secretions; Ivan Petrovich Pavlov; McGill University; Mentor; Physiologist

\section{La vie, les réalisations et l'héritage d'un grand chercheur canadien, le professeur Boris Petrovich Babkin (1877-1950)}

Le présent article récapitule la vie et les réalisations du professeur Boris Petrovich Babkin (MD D. Sc. LL. D.). L'histoire ne mérite d'être écrite que si elle nous informe sur l'avenir. Par conséquent, la présente analyse historique se termine par une description de ce que les gastroentérologues d'aujourd'hui et de demain pourront tirer de la vie du docteur Babkin. La docteur Babkin est né en Russie en 1877. Diplômé en médecine de l'académie médicale militaire de St. Petersburg, en Russie, en 1904, il n'était pas attiré par la pratique clinique et, après quelques hésitations entre l'histoire de la médecine et les sciences fondamentales, il est entré au laboratoire du professeur Ivan Petrovich Pavlov. Bien qu'il ait conservé un intérêt pour l'histoire, dans le milieu captivant de Pavlov, il est devenu passionné de physiologie du système gastro-intestinal. Il a évolué rapidement en Russie et est devenu professeur à l'université d'Odessa. En 1922, il a critiqué la révolution bolchévique et, après un bref emprisonnement, on lui a ordonné de quitter la Russie. Avec sa famille, il a été invité par le professeur EH Starling (le découvreur de la sécrétine) à son département de l'University College de Londres, en Angleterre. Deux ans plus tard, on lui a offert un titulariat au Canada, à l'université Dalhousie de Halifax, en Nouvelle-Écosse. Après quatre ans à cette université, il est arrivé à l'Université McGill de Montréal, au Québec, en 1928, à titre de professeur de recherche. Il y est demeuré jusqu'à la fin de sa carrière. Entre 1940 et 1941, il a présidé le département et, après sa retraite, il a poursuivi ses activités de professeur de recherche. À l'invitation de Wilder Penfield, neurochirurgien de renommée internationale, le docteur Babkin est devenu chercheur au département de neurochirurgie, où il est resté jusqu'à son décès en 1950, à l'âge de 73 ans.

Ses principales réalisations sont reliées à l'adoption du concept d'interaction cerveau-tractus digestif-cerveau et à l'influence de ce concept sur la motilité et sur l'interface de multiples cellules, nerfs et hormones avec la fonction sécrétoire. Il a joué un rôle prépondérant dans la redécouverte de la gastrine. Il a fondé une célèbre école de physiologues gastro-intestinaux à l'Université McGill. Il a soutenu ses stagiaires et les a aidés à asseoir leur carrière. Il a reçu de nombreux hommages : un D. Sc. à Londres, en Angleterre, et un LL. D. de l'université Dalhousie. De plus, il est lauréat de la médaille Friedenwald de l'American Gastroenterological Association pour son apport d'une vie à ce champ de compétences.

Le docteur Babkin nous a enseigné son abord philosophique de la physiologie, son dévouement envers ses disciples et sa gentillesse en tout. Pardessus tout, il a démontré qu'il est possible d'obtenir une reconnaissance internationale en publiant surtout dans des journaux canadiens. C'est un exemple à suivre. 
Tn response to a request by Dr Paul Adams, Editor-in-Chief of The Canadian Journal of Gastroenterology, to prepare a historical review on Dr Babkin, I undertook this task with pleasure, remembering that on my arrival to Canada, Dr Babkin was responsible for helping to provide my first job in Canadian science. Soon after I arrived in Montreal, Quebec, in 1949, I met Dr Babkin based on a letter by my previous mentor, Dr Edouard Frommel, Professor of Pharmacology in Geneva, Switzerland, who knew Dr Babkin well (1); at that time, they were both researching the effect of quinine and atabrine on the autonomic nervous system (2-6), and my thesis was also on this subject (7). Based on this common interest and after a personal encounter, Dr Babkin was instrumental in arranging for my first appointment in Canada as Lecturer of Pharmacology at McGill University, Montreal, Quebec. Unfortunately, our acquaintance was short lived, because he died in 1950, one year after I met him.

When I met Dr Babkin in 1949, he had retired from his post of Head of the Department of Physiology (Figure 1), but remained Research Professor of Physiology. At the invitation of the world-renowned neurosurgeon, Dr Wilder Penfield, he worked as 'Fellow of the University' and Research Fellow at the McGill Department of Neurology and Neurosurgery. At that time, I did not realize that it was during this period that he did one of his most pioneering works - localizing gastrointestinal (GI) function in the brain (8-12). As a young, immigrant physician, I had little knowledge of the grandeur and loneliness of this recently found friend who treated my wife and me with warmth, and showed deep understanding of the difficulties that a recent immigrant physician may have encountered. When we met him, although many of his colleagues admired him, he appeared to be a very lonely man. Later I discovered that he lost his wife, the well-known histologist Dr Helene Soloviev, 10 years before in 1939, his eldest daughter as a result of the Russian Revolution and his younger daughter (the ballet dancer Xenia Kernan) in 1944 (13,14). He lived alone in one of the rooms reserved for senior faculty at the very austere and impressive Faculty Club of McGill. My wife and I were invited on several occasions to the Club, which, at that time, did not admit lecturers or women in the general reading room. Because of my wife, we had to eat in a dining room in which women were permitted to enter. We immediately felt what was later stated by Carlson (15): "By his sympathy and assistance to others, Dr Babkin proved himself a true humanitarian”, and based on "his inherent kindness and sympathetic understanding" (15), he helped many newcomers, including myself. Most importantly, when we started to discuss research, his eyes lit up, and he shared his enthusiasm and love with me, as with many of his disciples, for the ongoing new developments and approaches to the physiology of the digestive tract. It is during these discussions that I decided that my future line of research would be in gastroenterology.

Having known him for only a short time, what follows, in addition to my own reading of his work, has been obtained from several obituaries regarding his life and achievements (13-16), and by browsing the archives of the Osler Library at McGill <http://www.health.library.mcgill.ca/osler/>.

Dr Babkin's work demonstrates a complete circle of understanding of the effect of the nervous system on the gut. In his youth, he studied the effect of nerves on the GI tract (17) and during his last years of investigation, he focused on the cerebral localization of GI function (8-12). Dr Babkin's work remains the basis of the recently rediscovered brain-gut-brain

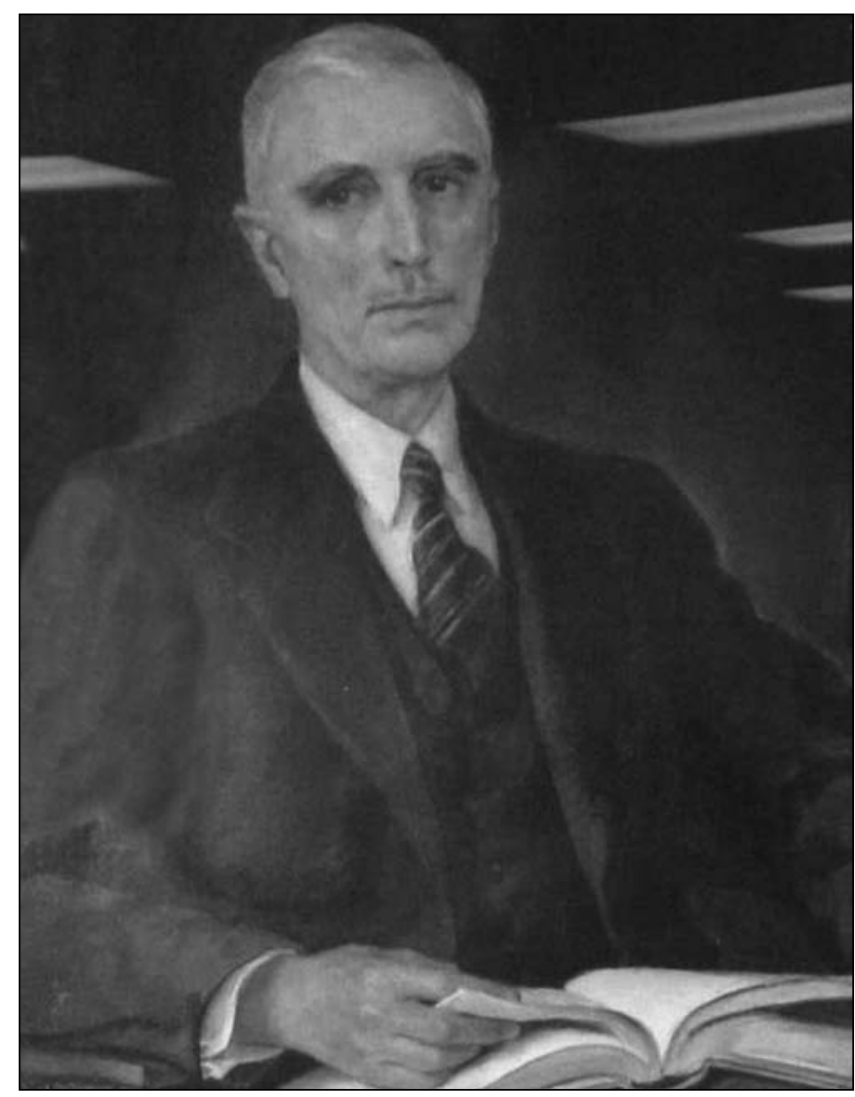

Figure 1) Portrait of Professor Boris Petrovich Babkin. This painting is hanging in the Department of Physiology, McGill University, Montreal, Quebec, commemorating Dr Babkin as a scientist and Head of the department between 1940 and 1941. Permission to use this photograph was provided by Dr Alvin Shrier, Chair of the department

interaction. His interests ranged widely. He made major contributions in several other fields, specifically in GI motility; he established the presently still accepted basic aspects of mechanisms of secretions; also, he had a major role in the rediscovery of gastrin.

\section{BABKIN'S LIFE HISTORY}

\section{Babkin's early achievements in Russia}

Dr Babkin, the son of an army officer, was born in 1987 in Kursk, Russia. He finished high school in St Petersburg and entered the Military Medical Academy (St Petersburg) in 1898. During his third year of study, he saw in the Academy vestibule an announcement for a gold medal for the best essay on one of several subjects, one being "The influence of artificial sutures of the skull on its growth and development in young animals". This theme was based on a suggestion by a French surgeon, Dr Lannelongue, that opening of the sutures of microcephalics may provide freedom to develop normally. Babkin approached Dr Bechterev for supervision. In this laboratory, however, there was little supervision or help from Dr Bechterev, and Babkin's work was not corrected or discussed. It was submitted as such to the Academy. Although he received the medal and the unsupervised work was published in a Russian neurological journal, it left him worried of its possible inaccuracy. He did not have time to reinvestigate it until 1942 and 1943 with the help of Professor Norris Giblin and Miss Armine Alley at McGill, and he found that his young, inexperienced findings were in fact correct (see pages 74-77 in 


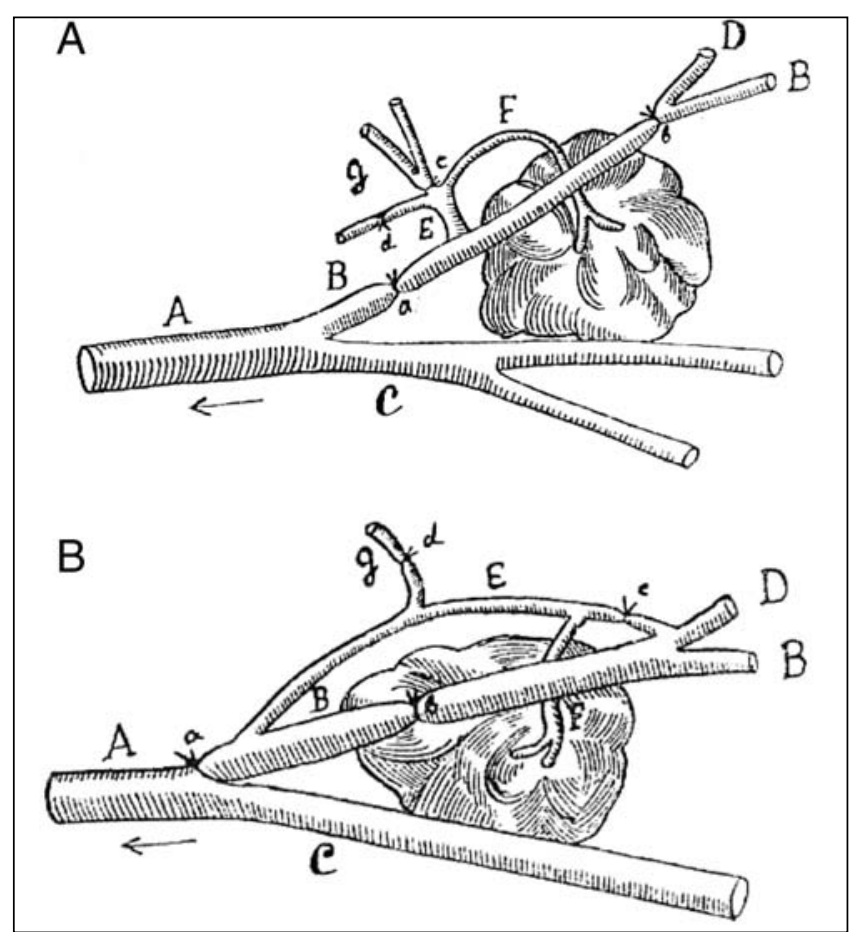

Figure 2) Increased blood flow in response to secretions of the submaxillaris gland of the dog. The detailed description indicates the care and detail with which Dr Babkin reported physiological experiments. Secretions were stimulated by placing meat extract in saline solution in the mouth of the dog to stimulate secretory flow. Resultant changes in blood flow were measured by a canula inserted in the isolated vein draining blood from the gland. Depending on the anatomical structure of the venous supply, each dog had to be prepared in a slightly different fashion. A Babkin's drawing of experiment on November 26, 1911. A Vena jugularis externa; B Vena maxillaris interna; C Vena maxillaris externa; D Vena auricularis magna; $a, b$, $\mathrm{c}$ and $\mathrm{d}$ are ligatures. All blood flow from the gland entered through $\mathrm{F}$ and E to the Vena axillaris interna, which was canulated to measure the flow. B Drawing of experiment of December 13, 1911. A Vena jugularis externa; B Vena maxillaris interna; C Vena maxillaris externa; D Vena auricularis magna; $\mathrm{a}, \mathrm{b}, \mathrm{c}$ and $\mathrm{d}$ are ligatures. Because of slightly different vascular anatomy, blood flow still went from the gland through $\mathrm{F}$ and $\mathrm{E}$ to the ligated section of the intubated section of Vena axillaris interna. Reprinted with permission from Springer Science and Business Media, Heidelberg, Germany: Babkin BP. Secretorische und vasomotorische erscheinungen in der speicheldrusen. Pflugers Arch Gesamte Physiol Menschen Tiere 1913;149:497-520

Babkin's biography of Pavlov [18]). Having finished medical school, he had little interest in clinical medicine, and intended to combine studies in the history of medicine with work in the research laboratory. In January 1902, he approached Professor Ivan Petrovich Pavlov, Chair of Physiology at the Institute of Experimental Medicine in St Petersberg, to join his laboratory. Dr Babkin became an outstanding disciple of Professor Pavlov and continued in the same field. He joined this laboratory unsure of whether his main interest was history of medicine or scientific work. Although his fascination with history and music was maintained throughout his life, under Professor Pavlov's tutorship his main commitment became science (14).

In 1902, Pavlov set him up to study the influence of soaps on the secretion of the pancreas. The results were reported at the Congress of Northern Naturalists and Physicians in Helsingfors in 1902 and were published in the proceedings of the Congress (referenced in 14). He was an assistant to Pavlov at the time when Pavlov began to change from work on digestion alone to the problem of conditioned reflexes. Based

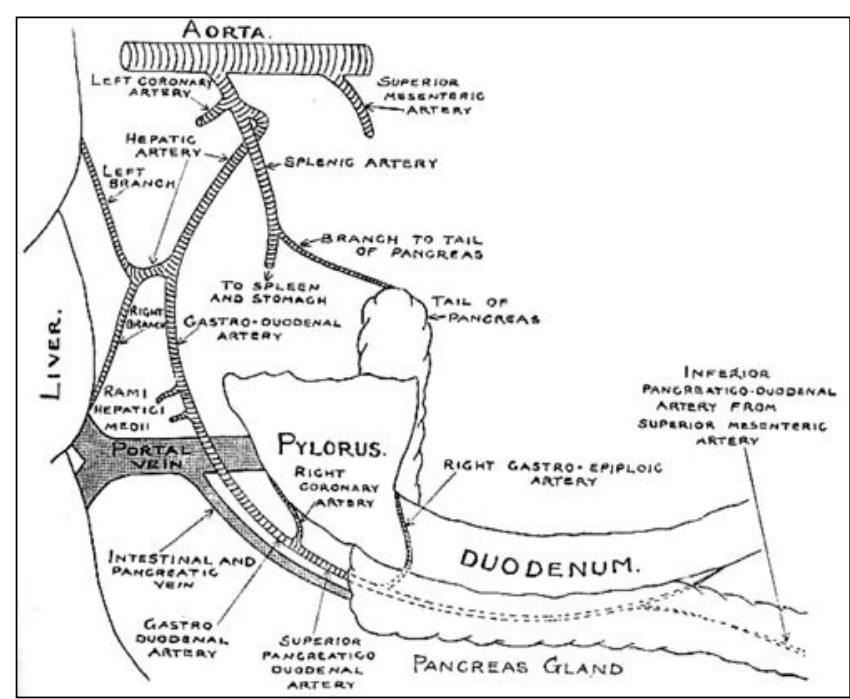

Figure 3) Schematic demonstration of experimental preparation of isolated pancreas. Note the detail of the drawing. This preparation was used by Babkin in several later experiments. Reprinted with permission from Blackwell Publishing, 9600 Garsington Road, Oxford, Great Britain: Babkin BP, Starling EH. A method for the study of the perfused pancreas. J Physiol 1926;61:245-7

on this experience, Dr Babkin, throughout his scientific life, continued to combine studies of the effects of the nervous system on GI function. Many of his early papers were published in Russian, which few Europeans or Americans could read. His first major papers in German were published in Pflügers Archive $(19,20)$. In these studies (in which, in the fashion of early physiologists, he described each experiment separately), he established that discharges from the salivary gland were stimulated by parasympathetic and not sympathetic nerves $(19,20)$. Figures $2 \mathrm{~A}$ and $2 \mathrm{~B}$ demonstrate the care with which he organized and described each experiment. His findings contradicted the established Heidenhein's theory of 'secretory' and 'trophic' nerves. This created controversy and thus exposure outside of Russia. Next, his monograph "Die äussere Sekretion der Verdaungsdrüsen" ("External secretion of digestive glands") was published in German in 1914 by Springer in Berlin, Germany ([21] quoted by [14]), providing him an even wider audience.

\section{Immigration and early times in the west}

Between 1915 and 1922, Dr Babkin was Professor of Physiology at the University of Odessa, Ukraine. Here, his main work was on glandular secretion, intestinal motility, their chemical stimulation and the correlation of the two. Because of his liberal attitude, he was upset by brutalities of the Russian revolution. In 1922, he was denounced to the authorities as disloyal and was thrown in prison in Odessa. Ten days later, he was exiled from Russia. By then, his monograph on the external secretions of digestive glands (21), which had been published in German, gave him international reputation to be invited with his family by Professor EH Starling to his department at University College, London, England. Here, he worked in a world-renowned environment. Starling and Bayliss (22) discovered secretin and established the concept of endocrinology (22-24). In this laboratory, Dr Babkin flourished and became interested in the interaction of nerves, chemical transmission and endocrine secretions (25). He described, with Starling, a new method of perfusing the pancreas (26). Figure 3 indicates the complexity and detail with 

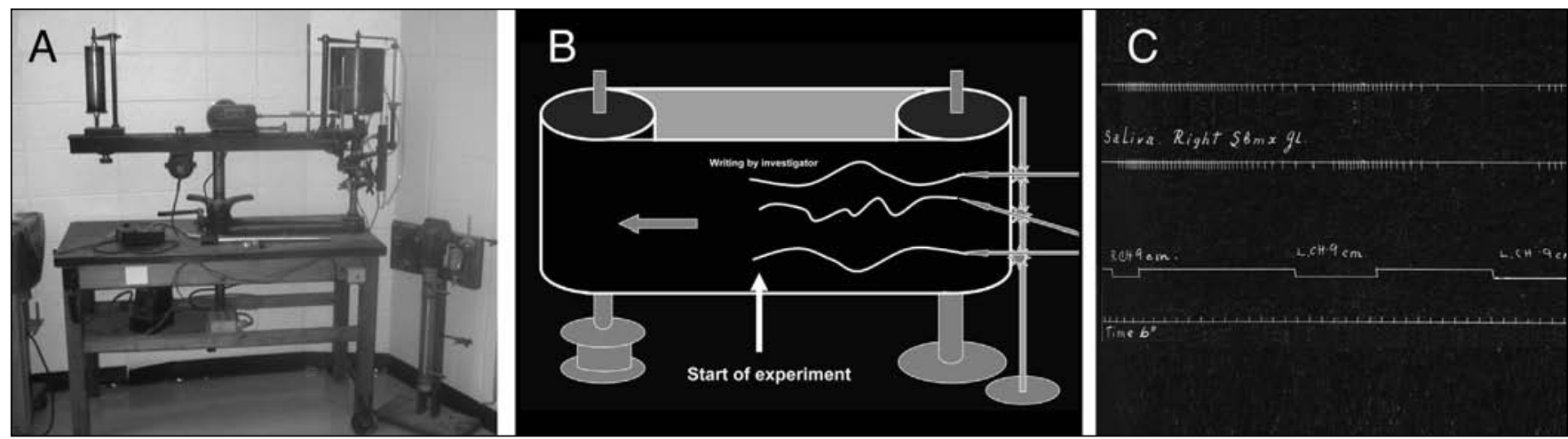

Figure 4) Secretory stimulatory substance released in response to chorda tympani stimulation. Demonstration of transmission of this substance from one salivary gland to the one on the other side. Complex surgical preparation allowed blood flow of one gland to perfuse the other. Kymographs were used to demonstrate the event. A Kymograph of the Department of Physiology, McGill University, Montreal, Quebec. The picture was obtained from the department. Ms Jay Bhat kindly arranged to have this exhibit rephotographed for the present publication. This equipment may have been used by Boris Babkin. B Schematic representation of kymographic technique. Kymographs were the recording techniques available to record analogue physiological events before World War II. Electronic recorders were developed during the war. They became available in the early 1950s for science. Kymographs carried touch-sensitive, charcoal-coated paper, which was prepared by holding it over fumes of burning benzene. The paper moved at preset speeds. Styluses traced continuous records. The recording stylus could be connected to various events: blood pressure, respiration, drop count, action potentials, electrical stimulation records, etc. The imaginary experiment on this figure started at the white arrow and the drum slowly moved away from the styli (grey arrow). The investigator rapidly took note of events on the paper as it moved (see writing at top). After each experiment, the tracing had to be carefully removed and rapidly fixed. This took two people. After cutting the paper, which was approximately $3 \mathrm{~m}$ long, one held it up high and the second placed it in a container of shellac and pulled it slowly through until the material was fully fixed in shellac. One of the most important functions of a research technician, or graduate student was to successfully prepare the paper and fix it without smearing the data. Appropriate sections were then used to publish analogue data. C Tracing demonstrates the transmission of the chorda tympany effect to the submaxillary gland on the other side. Upper tracing: Salivary flow of the right submaxillary gland. The excretory duct was canulated and drops of saliva fell on the indicator. Each downward line indicated a drop of saliva. The rate is indicated by the frequency of the drop count. Note that stimulation of the left chorda tympani released a substance that perfused into the right gland, initiating salivary flow. Middle tracing: Downward deflection records of electrical stimulation, first of the right, and the second and third of the left, chorda tympani. Note that stimulation of the left nerve resulted in increased salivary flow of the right gland. Lowest tracing: Indicates time by $6 \mathrm{~s}$. The writing is that of one of the authors done before finally fixing the tracing. Reprinted with permission from the Royal Society of Canada: The Academies of Arts, Humanities and Sciences of Canada, Ottawa, Ontario: Babkin BP, Alley A, Stavraky GW. Humoral transmission of chorda tympany effect. Trans R Soc Can 1932;26:89-107

which Babkin described his experiments, and reflects how knowledge was disseminated during the early 20th century.

It was quickly recognized what a loss he was to Russia, and several invitations came from there - one of them from Pavlov, who, at that time, retired; he was offered his own Chair at the Military Medical Academy. Dr Babkin declined, and wishing to come to North America, he accepted an invitation as instructor from the Washington University in St Louis (Missouri, USA). Canada quickly recognized his value, and as soon as he reached the American continent, Dalhousie University, Halifax, Nova Scotia, offered him the position of Chair of Physiology. He arrived in Halifax in the summer of 1924. There, he regained his dignity and undertook with enthusiasm his responsibility of Professorship in Physiology. He had major difficulties with the English language. His language difficulty and foreign accent made him anxious that his medical students would not understand him. "While the latter circumstance did occur in numerous instances, the personality and great ability of the man compensated and impressed his students in an indelible manner" (14). In his early years, he wrote his lectures in Russian and had his manuscripts corrected for grammatical error (14). His first paper from Halifax was on chemical stimulation of GI motility, published in the Canadian Medical Association Journal (27). This article reviewed the work of many investigators in intestinal motility and provided 63 references, many of his own work. It updated the English literature on studies by Russian investigators previously never published in English. Reading it today, one cannot help but be impressed that he knew all the principles of GI motility we know today, and all we have added since are details. In this paper, Babkin also established two principles that he carried through all his life: providing a link between English and Russian investigators and publishing much of his work in Canadian journals. We can learn from him that one can receive the highest international honors by publishing mainly in Canadian journals.

\section{Research at McGill University}

After four years in Halifax, in 1928, he accepted the post of Research Professor of Physiology at McGill University, where he worked until his death. He chaired the Department between 1940 and 1941, and after retirement, he continued in a research position. It is at McGill that he could materialize his broad interest in various aspects of GI physiology. He reinvestigated the innervations of the salivary glands and demonstrated that stimulation of chorda tympany in the presence of physostigmin releases a substance that can be transferred from one gland to the other (28). In a complex set of experiments in cats, he connected the venous outflow of one submaxillary gland to that of the other. By opening and closing the connection, he demonstrated that stimulation of chorda tympani on one side released a substance that stimulated secretion by the gland of the other side (Figure 4A, 4B and 4C). The transmitted substance was later found to be acetylcholine, but Babkin's observation occurred one year before Feldberg and Krayer (29) identified acetylcholine as the parasympathetic transmitter in 1933. With his ongoing studies, Babkin developed a concept of the autonomic nervous system that became the standard of knowledge of his time. In his presidential address to the Royal Society of Canada, by 1946 (in the 
bibliography he gives credit to many of his disciples), he had an astonishingly clear picture of the antagonistic and synergistic phenomena of the transmitters (30).

Babkin's studies of the stomach dealt with correlating and differentiating nervous and chemical phases of secretions. He was the first to describe that acetylcholine, histamine and gastrin induce different compositions of gastric juice and that the composition depended on the type of cell (parietal, chief or mucus) being stimulated. He proposed (Figure 5) that histamine was released by acetylcholine and was secondary to vagal stimulation (31). Up until recently, contrary to Babkin's concept, the opinion was generally accepted that there was equal stimulatory and possibly synergistic effects of acetylcholine, gastrin and histamine on the parietal cell (32). Only in 1996 was Babkin's theory confirmed by demonstrating that the vagus stimulates the neuroendocrine enterochromaffinlike cells to release histamine, which then stimulates acid secretion of the parietal cell $(33,34)$. In the same paper, Babkin suggested that sympathin was not the only inhibitor of secretion, a concept that was later accepted and described as 'nonadrenergic noncholinergic inhibitor', which after many transitions, today, may be nitrous oxide (Figure 5).

With his students, Babkin described the effect of histamine on gastric parietal, mucoid and peptic cells, and compared the action of histamine with nervous stimulation (35). They studied the use of histamine on gastric secretory activity (36) and, with DR Webster, demonstrated that insulin, by causing hypoglycemia, stimulates central vagal nuclei. In contrast to histamine, which stimulates parietal cells, insulin-stimulated secretion can be abolished with vagotomy and by atropine. Dr Babkin was asked to write an editorial on the usefulness of the histamine versus insulin stimulation to differentiate between vagally stimulated (insulin) and parietal mass (histamine effect) secretions (37). At the time, peptic ulcer was treated with vagotomy, antrectomy and pyloroplasty, and it was necessary to know whether a recurrent ulcer was due to inadequate vagotomy or insufficient resection of the gastrin containing antrum. His concepts of basic gastric research were an attempt to correlate physiological findings to proposed surgical therapy (38).

After describing the effect of soaps on pancreatic function while still in Pavlov's laboratory, at McGill, he and his students investigated the effects of different agents on pancreatic secretions. They found that similar to the salivary glands and the stomach, the compositions of pancreatic secreta differed depending on the stimulus (39) and on the presence of substances in the circulation (40). Based on studies on multiple secretory organs, Dr Babkin established that in diverse organs, various stimuli caused different composition of secretion, each coming from different cell types. He proposed a new cellular theory, which is still correct, that digestive glands consist of compound structures in which various cells are controlled by different nerves or hormones (41).

\section{BABKIN'S ROLE IN ESTABLISHING THAT GASTRIN EXISTS}

The story of gastrin is a tragic one. Based on the concept of the discovery of secretin in the duodenum by Bayliss and Starling (22) in 1902, John Sydney Edkins of St Bartholomew's Hospital Medical School in London, England, suggested in 1905 that a 'gastric secretin' (gastrin) in the antrum that may have been responsible for the release of gastric acid $(42,43)$. Unfortunately, Barger and Dale (44) extracted histamine from

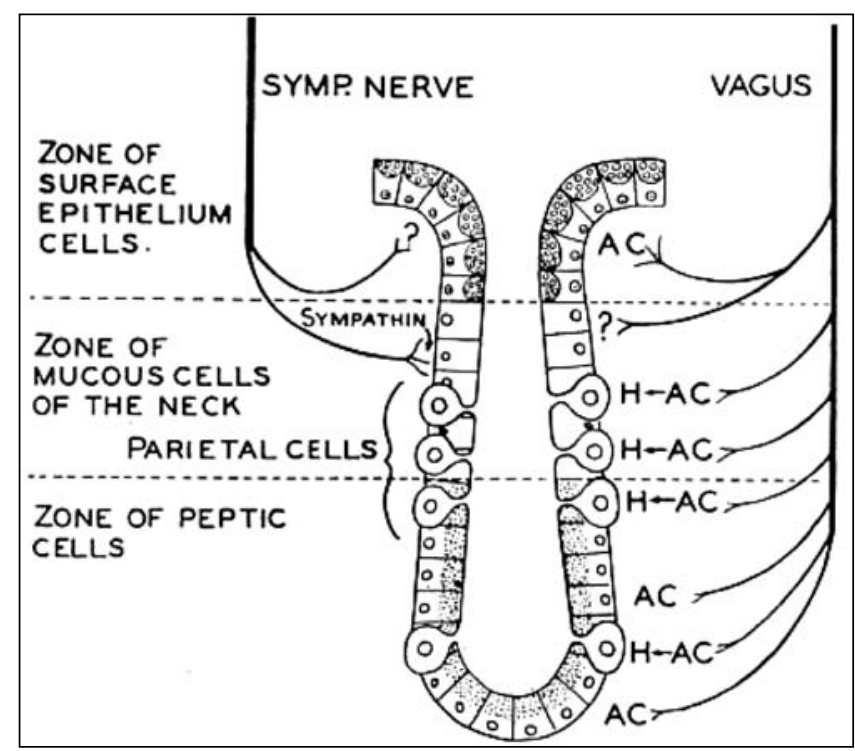

Figure 5) Babkin's concept of the relations of acetylcholine (AC) and histamine $(H)$. Note that in this scheme, the vagus releases $A C$, and that this stimulates secretion of the mucus and chief cells. In contrast, the parietal cell is directly stimulated by $\mathrm{H}$, which is released by $\mathrm{AC}$ from an as yet unknown site. This concept was later confirmed by showing that AC stimulates enterochromaffin-like cells that then release histamine. Babkin also indicated that sympathin is not the only inhibitory substance. This concept was later described by others as the 'nonadrenergic noncholinergic' inhibitor, and then as nitrous oxide. Reprinted with permission from the publisher. (c)1938 CMA Media Inc, Ottawa, Ontario: Babkin BP. The abnormal functioning of the gastric secretory mechanism as a possible factor in the pathogenesis of peptic ulcer. Can Med Assoc J 1938;38:421-9

ergot and later from the gastric mucosa. Because Edkins' extract also caused some of histamine's vascular effects, his finding was disregarded for almost 30 years. AC Ivy found that histamine or 'gastrin' did not provoke gastric secretion (45). Sacks, Ivy, Burgess and Vandolah stated in 1932 that "either that histamine is the gastric hormone, or if not, there is no gastric hormone, or the gastric hormone has never been extracted from pyloric mucosa" (46). Because of the considerable importance of these American investigators, Edkins findings were ridiculed by the scientific community, and it took until after his death to prove that gastrin really exists. In contrast to the general opinion, Babkin, based on his own experiments, continued to support the presence of gastrin, a pyloric acid stimulatory hormone. In 1934, in response to the paper by Sacks et al, he described experiments in which putting food in an isolated and denervated pyloric pouch caused secretion in the isolated fundus (Figure 6) (47). Furthermore, the composition of the fundal secretions was different from that produced by histamine (48), and the pyloric stimulated secretions were not accompanied by histamine's vascular effect (47).

To prove that gastrin was not histamine, Babkin considered that only someone well trained in chemistry could separate the two. It was fortuitous that between 1910 and 1913, Babkin met Dr Simon Andrew Komarov when they both worked in Dr Pavlov's laboratory - Babkin as an assistant and Komarov as a student. Komarov was born in Lugansk, Russia in 1892. After his work at the Military Medical Academy in St Petersburg, in 1915 he completed his medical education in Kharkov, Russia, obtaining an MB. He did his internship in medicine at the University of Kharkov. Similarly to Babkin, Komarov found 


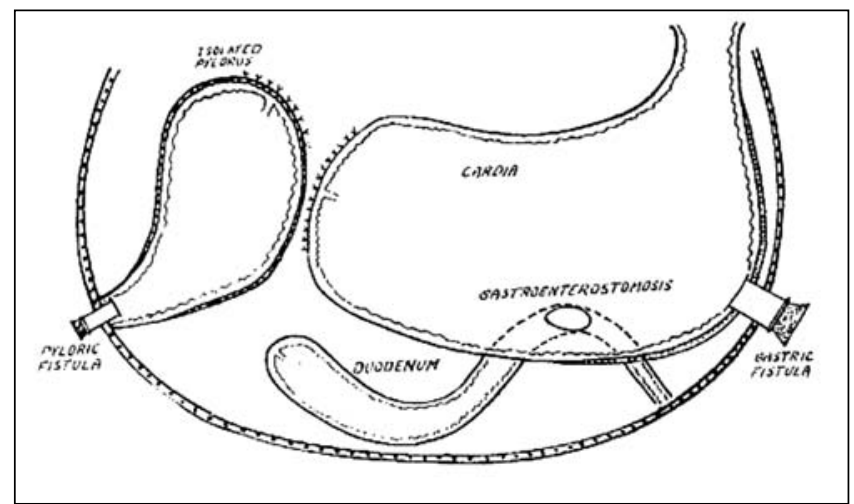

Figure 6) Diagram of an experiment to prove the physiological presence of gastrin. Diagram of the gastrointestinal tract of a dog with a gastric fistula, gasroenterostomosis and an isolated pyloric pouch. Reprinted with permission from Springer Science and Business Media, Heidelberg, Germany: Babkin BP. The "chemical" phase of gastric secretion and its regulation. Am J Dig Dis Nutr 1934;1:715-21

that basic science was his vocation, and, between 1916 and 1922, became an assistant in biochemistry and organic chemistry. Due to his dislike of communism, in 1922, Komarov left Russia and immigrated to Latvia. He worked at the University of Riga, Latvia, as Prosecutor of Physiology between 1922 and 1929. In Riga, he obtained an MD degree in 1926 (49,50). Two years after Babkin was established as a Research Professor at McGill, he invited Simon Komarov as a Research Assistant to the Department of Experimental Medicine (1930 to 1939) and, from 1939 to 1942, as a Lecturer in the Department. In 1942, Komarov left McGill to be the Director of Chemistry, Medical Research Laboratory Fels Research Institute, Temple University School of Medicine in Philadelphia, USA. While at McGill, Komarov extracted a histamine-free gastric secretory stimulant from the pyloric mucosa that increased acid, pepsin and volume secretion. It did not stimulate biliary and pancreatic secretion and, thus, was different from secretin. It fulfilled the criteria for a new hormone: gastrin. Komarov first presented this as a verbal communication (introduced by Dr Babkin) at the Meeting of the Society of Experimental Biology and Medicine in 1938 (51). The findings presented are shown in Figure 7. Because he pursued a hypothesis that the hormone, similar to secretin, was a polypeptide, he separated it from histamine using methods to extract polypeptides. The work to separate took enormous mental and physical effort, and it took a further four years before he published the details of preparation of the extract (52) and its final physiological function (53), both in the Revue canadienne de biologie.

Although the work, mainly consisting of organic chemistry, was entirely that of Komarov, it could not have been done without the ongoing support, patience and consideration by Babkin. One of their close coworkers, Dr Friedman, who was in the Babkin laboratory at the time of the separation $(54,55)$, writes in the obituary in memoriam of Komarov that, typical of his hard work, in some experiments he needed the collection of up to $300 \mathrm{~L}$ of canine gastric juice. Can one visualize what this did to the general running of the unit, especially because Komarov may not have been easy to live with? Friedman writes (49):

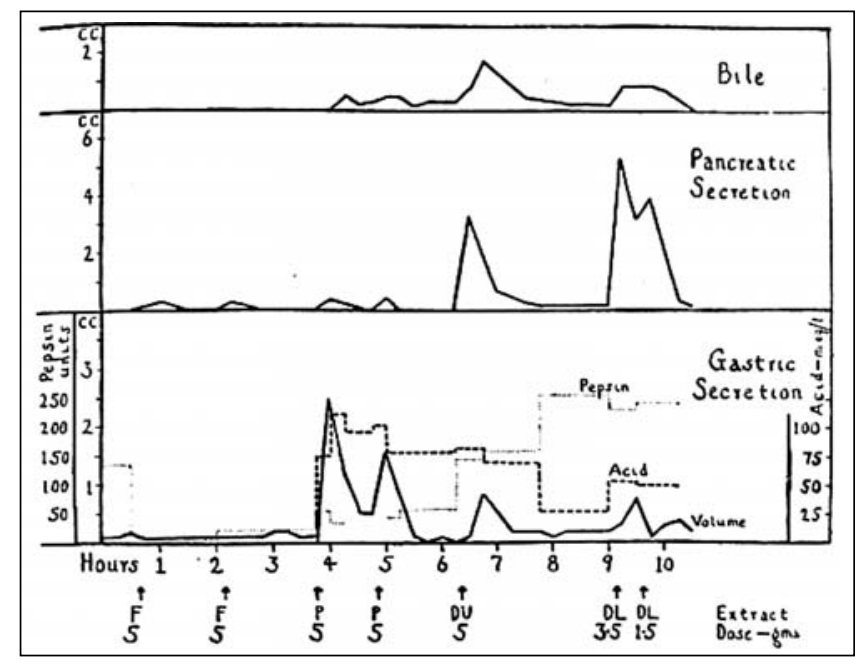

Figure 7) Simon Komarov's proof of gastrin (3). Effect on gastric, biliary and pancreatic secretion of substances which were devoid of histamine effect. Extracts made from the mucous membrane of fundus $(F)$, pyloric region $(P)$, upper duodenum (DU) and lower duodenum (DL). The numbers below the letters denote the weight of mucosa equivalent to the dose of extract administered. Upper tracing: Bile flow. Middle tracing: Pancreatic flow. Lower tracing: Gastric volume and acid and pepsin secretion. Left markings: pepsin secretion in units, and volume in $\mathrm{mL}(\mathrm{cc})$. Right markings: acid in meq/L. Bottom markings: time in $h$. Note that only the pyloric extract stimulated gastric volume and acid and pepsin secretion. Reprinted with permission from the Society of Experimental Biology and Medicine, 197 W Spring Valley Avenue, Maywood, New Jersey, USA: Komarov SA. Gastrin. Proc Soc Exp Biol Med 1938;38:514-6

\begin{abstract}
"Komarov's years at McGill were not only productive in his research, but also in his personal life. He married Olga Piotrowsky ... Her calm efficiency was the solvent for Simon's sharp responses to anything that interfered with his daily routine. It was Olga who smoothed out the problems of every day life ... She not only encouraged him to report his many worthwhile contributions to GI physiology, but helped him to overcome his natural shyness".
\end{abstract}

Komarov became, on his own, one of the world's most outstanding physiologists while he worked in Philadelphia. After his death in 1966, the American Journal of Digestive Diseases established a special issue dedicated to Komarov. In this "festschrift" they collected papers from individuals affected by Komarov's work or personal contact. In the introduction, Bralow states: "Komarov emerged as one of the world's outstanding GI physiologists and it seems appropriate to trace the descent of the mantle of genius from Pavlov to Babkin, to Komarov" (50 [page 76]).

\section{BABKIN AND HIS SCHOOL}

It was at McGill that Babkin established his own school and trained many postgraduate students, many of whom soon established their own research excellence. A short list of his disciples is provided in the obituary by de Burgh Daly et al (14). In the present history, I decided to mainly use Babkin's reviews, which were mostly published under his own name. This does not indicate that he published most of this work without giving credit to his students. In fact, the contrary is 
true. The bibliography of each review provides the original work published by his trainees in which most are first or second authors in the original publication. Many became well-known investigators in Canada, the United States or Europe. Of his disciples, several stayed at McGill. Some I knew while I was on staff in Pharmacology and later at the Royal Victoria Hospital, Montreal, Quebec. Dr FC MacIntosh, who, when I arrived, was Professor and Head of the Department of Physiology, was extremely helpful in my early days, the Department of Pharmacology being one floor above that of Physiology. He and Professor Raymond Stehle, Head of Pharmacology and Kenneth Melville, who worked with Babkin on atabrine (6), carried me through the same anxieties about language and accent Boris Babkin had experienced in Halifax. Once in clinical training and then staff at the Royal Victoria Hospital, I met Dr Babkin's clinical postgraduate students. JC Armour and DR Webster, gastric surgeons, were close friends of Dr Richard McKenna (the first president of the Canadian Association of Gastroenterology [56]) and were members of our McGill gastroenterology group. Even after their postgraduate training (57), during World War II, when Webster was Surgeon Commander in the Royal Canadian Navy, they carried out studies with Dr Babkin on how to preserve the stomach after deprivation from arterial supply (58). Dr Arthur M Vineberg, another postgraduate student (35), became a cardiac surgeon. He originated the concept of coronary bypass surgery and was the first to achieve successful implants from intercostal arteries to the heart. Both approached surgery with the judgment expected from disciples of Babkin, and for a resident and later junior staff, I found my association with these surgeons awesome.

After retirement, Babkin continued as Professor of Physiology until 1947, when he was invited by Professor Wilder Penfield to continue his work as Fellow of the University and Research Fellow at the McGill Department of Neurology and Neurosurgery. It was in this laboratory that he was the first to demonstrate, in experimental animals, the representation of several functions of the GI tract in the cerebral cortex. This work clarified the cortical inhibition of gastric motility $(8,11)$, cortical representation of feeding pattern (10) and, putting this together (11) with his very early studies in Pavlov's laboratory on reflex regulation, he described the central location of the reflex connection of motility of the pylorus (12). Establishing the relationship of reflex response and function of digestive organs and then demonstration of their cerebral location (8-12), Babkin was the first to establish the main concepts of brain-gut-brain interaction.

\section{WORLDWIDE APPRECIATION OF BABKIN'S CONTRIBUTIONS}

Professor Babkin received many honours throughout his scientific career. In 1924, he was awarded a DSc at the University of London, England. He received an honorary Doctorate of Law from Dalhousie University in 1943. He was elected a Fellow of the Royal Society of Canada in 1930 and was President of its Biological Sciences section between 1945 and 1946. He was the recipient of the Flavelle Medal of the Royal Society of Canada in 1946. He was President of the Canadian Physiological Society between 1944 and 1945. In the spring of 1950, he was pleased to be elected a Fellow of the Royal Society of London and was prepared to be invested in England. Unfortunately, his death the same year took him away from personally receiving this honour. His appointment to Emeritus

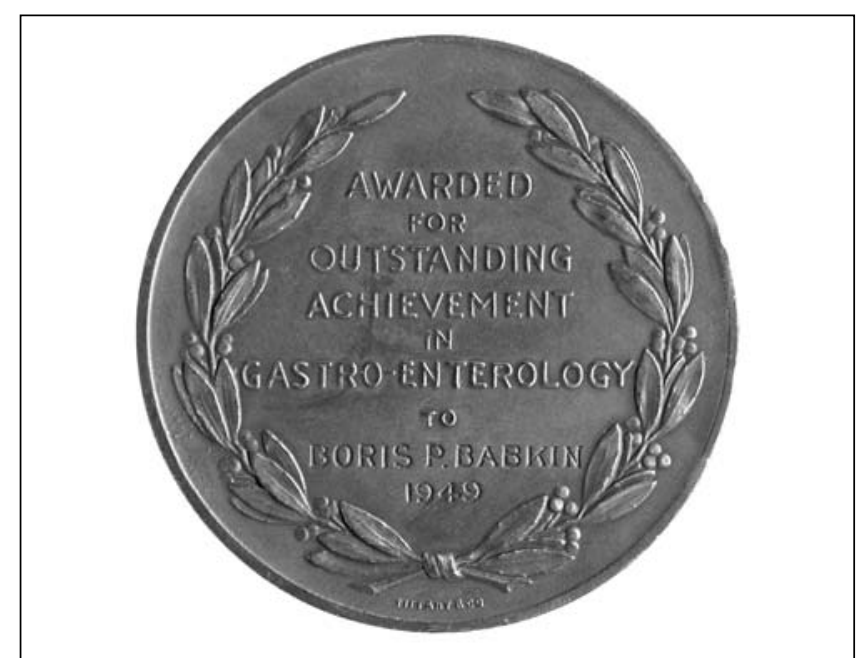

Figure 8) The Friedenwald Medal presented to Boris Babkin in 1949. This medal is the highest award of the American Gastroenterology Association

Professor at McGill was announced posthumously. Dr Babkin remains greatly respected at McGill. His portrait hangs in the Physiology Department, and its Chair, Dr Alvin Shrier, provided the picture of Dr Babkin to be included in this historical essay with pride and pleasure (Figure 1).

One of the honours that Canadian gastroenterologists and scientists in digestive diseases appreciate most is the Friedenwald Medal from the American Gastroenterological Association (AGA) (Figure 8). Dr Julius Friedenwald was a gastroenterologist on the staff of Johns Hopkins University in Baltimore, Maryland, USA. He held many teaching positions and was a well-known author who published a number of books and articles. He was President of the AGA. Dr Friedenwald died at the age of 75 years in 1941. In his honour, the AGA established a Medal for highest distinction in research in this field. This medal is presented at Digestive Diseases Week (at the time of Babkin at the Annual Meeting of the American Gastroenterological Association), and the text used for the presentation is published in a close subsequent issue of Gastroenterology. The list of the yearly awardees is a panorama of outstanding gastroenterologists and scientists (Table 1). Dr Babkin received this honor in 1949, and the speech about him was given by his friend Dr Walter Alvarez (59). He described his personal friendship to Dr Babkin, and then proceeded to talk about Dr Babkin's devotion to his students and theirs to him. He described some of the attributes I have seen, and his devotion interest to music and history. $\mathrm{He}$ then commented "Today, past 70, but still young in body and mental outlook, Dr Babkin is working away in Penfield's Neurologic Institute at McGill. Still a student, he is an example to all of us older men of how well a man can use the years after his official retirement" (59).

Dr Babkin died during his sleep on a train the night of May 2, 1950 on his way back from Philadelphia to Montreal, where he was returning from the annual meeting of the AGA in Atlantic City, New Jersey, USA. His contributions to GI physiology have been continued by his disciples, and although I was not his student, it was he who influenced me to take up the field of GI physiology. 
TABLE 1

Award recipients of the Julius Friedenwald medal

\begin{tabular}{|c|c|}
\hline 1941 Walter B Cannon & 1974 Charles F Code \\
\hline 1942 Max Einhorn & 1975 Joseph B Kirsner \\
\hline 1943 Thomas R Brown & 1976 Thomas P Almy \\
\hline 1944 AJ Carlson & 1977 Charles J Best \\
\hline 1945 Lewis Gregory Cole & 1978 Morton I Grossman \\
\hline 1946 Frank H Lahey & 1979 Hugh R Butt \\
\hline 1947 George B Eusterman & 1980 Horace W Davenport \\
\hline 1948 Franklin W White & 1981 Wade Volwiler \\
\hline 1949 Boris P Babkin & 1982 Thomas C Chalmers \\
\hline 1950 BB Vincent Lyon & 1983 Gerald Klatskin \\
\hline 1951 Walter C Alvarez & 1984 Henry D Janowitz \\
\hline 1952 Sara M Jordan & 1985 Kurt J Isselbacher \\
\hline 1953 Burrill B Crohn & 1986 Fred Kern, Jr \\
\hline 1954 Albert FR Andressen & 1987 Robert M Donaldson, Jr \\
\hline 1955 Frank Charles Mann & 1988 Frank P Brooks \\
\hline 1956 Donald C Balfour & 1989 Marvin H Sleisenger \\
\hline 1957 T Grier Miller & 1990 Rudi Schmid \\
\hline 1958 AH Aaron & 1991 Cyrus E Rubin \\
\hline 1959 Russel S Boles, Sr & 1992 Basil I Hirschowitz \\
\hline 1960 Chester M Jones & 1993 John S Fordtran \\
\hline 1961 Jesse L Bollman & 1994 Alan F Hofmann \\
\hline 1962 Henry L Bockus & 1995 John T Farrar \\
\hline 1963 Walter L Palmar & 1996 William Silen \\
\hline 1964 Lester R Dragstedt & 1997 David H Alpers \\
\hline 1965 Franklin Hollander & 1998 Eugene D Jacobson \\
\hline 1966 Dwight L Wilbur & 1999 Jerry S Trier \\
\hline 1967 J Arnold Bargen & 2000 Howard M Spiro \\
\hline 1968 Julian M Ruffin & 2001 Don W Powell \\
\hline 1969 Franz J Ingelfinger & 2002 Sidney Cohen \\
\hline 1970 Andrew C Ivey & 2003 Tadataka Yamada \\
\hline 1971 Hans Popper & 2004 Jon I Isenberg \\
\hline 1972 J Earl Thomas & 2005 Ralph A Giannella \\
\hline 1973 Leon Schiff & \\
\hline
\end{tabular}

\section{CONCLUSION:}

\section{WHAT DID BABKIN'S LIFE TEACH US?}

"How can we know where we're going if we don't know where we are coming from? This question applies as much to nations as it does to travellers, and it rings especially loudly in the ears of Canadians." These are the first sentences of the cover of the book Canada, A People's History, by Gillmor and Turgeon. This quote and the following is most apt, because this country was built by "courageous explorers ... many of them exiles from their homeland ... who rose to the extraordinary challenge of building Canada" (60). Babkin's life demonstrated in a minievent what one could see of so many Canadians displayed on the film production of the Canadian Broadcasting Corporation and its derivative book. Arriving with practically no English, writing his first papers in Russian (many of his Russian notes are still at the Osler Library at McGill), he learned English, worked hard, taught with excellence and, finally, brought honour to Canada as the recipient of many great international awards. There are several lessons to be learned.

Canada has benefited from immigration of scientists and physicians from all over the world. In gastroenterology, we have seen giants like Hans Selye (stress ulcer - Hungary), John Brown (motilin and gastric inhibitory peptide - England), Charles Philippe Leblond (stem cell of the epithelium France), Andrew Sass-Kortsak (Wilson's disease - Hungary),
Aron Rappaport (hepatic physiological lobule - Bukovina: Austrian-Hungarian Monarchy) and many others. This intellectual exchange was beneficial for Canada and also internationally, because many of their disciples went back to their own country. One of the more disturbing events occurring since the early 1990s was government's acceptance of the recommendations of the Barer and Stoddard (61) and the Romanow report (62), both of which suggested cutting down on employment of international graduates. Over the past 15 years, we have lost many outstanding investigators, who after obtaining research experience in Canada, left for the United States for clinical training, where many of them remained. Because of a shortage of physicians (63), the government's attitude has now been rethought and it now encourages the licensing of foreign graduates. However, it should be kept in mind that we do not only need clinicians but physician scientists, specifically clinical investigators $(1,64,65)$.

Babkin was trained as a physician, and although most of his work was as a basic scientist, his research questions were always related to clinical problems. His work followed the process of a clinical investigator, to first evaluate the problem on the whole animal and if this did not provide an answer, to move to isolated organs, then to the cell and, finally, to subcellular events (1). For instance, to find the best approach to peptic ulcer surgery, it was necessary to know whether the antrum released a gastric stimulant. Using isolated pouches, he demonstrated the physiological presence of this stimulant (47). For chemical proof, he invited Simon Komarov to isolate the physiological principle, an effort that took the latter several years (51-53). This extract led to the synthesis of gastrin by Tracy and Gregory (66) many years after Babkin's death. Every step was carefully carried out by the investigators based on understanding and devising the method for each event.

Over the past decade, due to designing rapid-response equipment, using mini quantities of material molecular biology has developed rapidly. Today, one can use machines that can determine proteins, RNA, DNA and many other subcellular events quickly. NanoDrop (www.nanodrop.com) advertises "1 $\mu \mathrm{L}$ drop samples, no cuvettes, 10-second measurement, broad spectral output" to measure nucleic acids and proteins. New England BioLabs (www.neb.com) advertises RheoSswitch for "precise, variable control of mammalian gene expression" and eBioscience (www.ebioscience.com) provides "authentic" cytokines. The natural outcome of the availability of these instruments is to develop research that tends to concentrate on utilizing these techniques, often on isolated cells. This type of research tends to remove itself from the kind of research that made the work of Babkin so remarkable. The time has come to find a midway where clinical and pathophysiological research and molecular biology meet. Fortunately, there are some Canadian clinical scientists who continue to fulfill this role.

Most of the obituaries of Babkin (13-15) and the presentation of the Friedenwald Medal by Alvarez (59) acknowledge his generosity to his coworkers and his devotion to facilitate their success. He never took credit for any of their work, the best example being that, although rediscovery of gastrin could not have been achieved without him, Komarov published this alone (51-53). Only when one reviews the story of gastrin does one connect its development to Babkin. This unselfish devotion is the example to follow, if scientists want to be remembered not only as great investigators, but also as teachers who established their own school and contributed to society through their disciples. 
Perhaps the most important lesson from Professor Babkin is that he considered it a duty to publish mainly in Canadian journals and was still able to attain international recognition $(2,5,6,27-31,36,38,41,54,55,57,58)$. Canadian scientists of today have abandoned this responsibility to our journals. To the detriment of our Canadian journals, they send their best papers to foreign publications. When asked why, the answer is that, to be successful in obtaining research grants from the Medical Research Council of Canada (MRC) and now, under its new name, the Canadian Institute of Health Research (CIHR), one has to publish internationally, because publishing in Canadian journals is considered of lesser value and lower impact. In Babkin's time, research support was provided by the universities, and there was no need for competition for money until the MRC was established in 1960 (67). This attitude by the MRC and CIHR committees to judge progress by the journal of publication rather then its content leads to a selfdestructive, vicious circle. If the best Canadian papers are not submitted to Canadian journals, our journals become weakened, and thus, has supported the above preconceived idea. Could we have changed this perception? Most successful investigators in gastroenterology are or were on MRC or CIHR committees, and some have attempted to initiate a change. However, in spite of numerous attempts to request a special gastroenterology panel from the MRC (56) and from the CIHR $(64,68,69)$, gastroenterology remains a part of the Institute of Nutrition, Metabolism and Diabetes and its grants are judged in the Experimental Medicine Committee. This committee judges submissions of five other specialties. To change this attitude, a consensus would have to be reached with scientists on the panel in other fields.
The problem of degrading publications in Canadian journals, however, is too important to be left to an agreement by single committees. It needs an overall decision by the CIHR council. The reputation of Canadian research is not only its scientists, but the value of their home journal. The goal of the CIHR, like that of Babkin's, should be to support not only Canadian researchers, but also our scientific journals. To achieve this (68), the CIHR council should insist that papers are assessed only on their scientific value and not where they were published. This would result in submitting more Canadian papers to our journals, creating increasing competition for acceptance, gradually further improving their already high standard.

ACKNOWLEDGEMENTS: The author is grateful for the ongoing support of the entire staff of the Bracken Health Sciences Library at Queen's University, Kingston, Ontario, under the direction of Suzanne Maranda. I would like to specially thank Anne B Smithers, Head of Technical \& Document Services, and her staff for finding many of the references, and Darlene Lake, the library's document services coordinator, and her staff for obtaining the many reprints quoted in this study. At McGill University in Montreal (Quebec), Pamela Miller, History of Medicine Librarian at the Osler Library, merits special thanks for providing guidance of finding the data on Drs Babkin and Komarov. Also thanked are Professor Dr Alvin Shrier, Chair of the Department of Physiology for providing a copy of Dr Babkin's painting, and his secretary Ms Jay Bhat for her kind reception on my visit and for arranging rephotographing of the exhibited old kymograph of the Department.

\section{REFERENCES}

1. Beck IT. Reflections on education - Machines or mentors: Mentors and mentorship. Education Excellence Lecture 2004. Can J Gastroenterol 2005;19:97-104.

2. Babkin BP, Ritchie TW. Effect of quinine on the parasympathetic innervation of the heart of the dog. Rev Can Biol 1945;4:345-68.

3. Frommel E, Beck IT. L'association de quinidine et de phenobarbital dans le traitment des affectiones cardiovasculaires. Praxis, Revue Suisse de Medicine 1948;46:1-2.

4. Frommel E, Beck IT, Vallette F. Les antimalariques de synthese (atebrine, rhodoquine, rhodopraequine et plasmochine) et le systeme nerveux vegetatif. Arch Sci 1951;4:186-8.

5. Babkin BP, Karp D. Effect of quinine and atabrine on gastric secretion (A preliminary communication). Can Med Assoc J 1947;56:137-41.

6. Babkin BP, Melville KI. Effect of quinine and atabrine on coronary flow in the rabbit heart. Rev Can Biol 1947;6:77-93.

7. Beck IT. L'action de l'Atebrine (Quinacrine) sur le system nerveux vegetative: Antagonisme entre l'atebrine d'une part et l'acetylcholine, l'adrenaline, l'histamine et la chlorure de Barium d'autre part. Universite de Geneve, Geneva: Faculte de Medicine, 1949.

8. Babkin BP, Speakman TJ. Cortical inhibition of gastric motility. J Neurophysiol 1950;13:55-63.

9. Babkin BP, Kite WC Jr. Gastric motor effects of acute removal of cingulate gyrus and section of brain stem. J Neurophysiol 1950;13:335-41.

10. Babkin BP, Van Buren JM. Mechanism and cortical representation of the feeding pattern. AMA Arch Neurol Psychiatry 1951;66:1-19.

11. Babkin BP. Cerebral cortex and gastric motility. Edinburgh Med J 1950;57:418-30.

12. Babkin BP, Kite WC Jr. Central and reflex regulation of motility of pyloric antrum. J Neurophysiol 1950;13:321-34.

13. Komarov SA, Friedman MH. B. P. Babkin 1877-1950. Gastroenterology 1950;16:511-4.

14. de Burgh Daly I , Komarov SA, Young EG. Boris Petrovitch Babkin. 1877-1950. Obituary Notices of Fellows of the Royal Society $1952 ; 8: 13-23$

15. Carlson AJ. Boris Petrovitch Babkin. J Neurophysiol 1950;13:389-90.

16. Obituary: Dr. Boris P Babkin. CMAJ 1950;62:621-2.

17. Babkin BP. The relative strength of the conditioned stimuli (quoted in: Daly, Komarov and Young: Obituary notices of the Fellows of The Royal Society: 1952;8:13-23). Proc Soc Russ Physicians,

St Petersburg (in Russian) 1911;78:44-65.

18. Babkin BP. Pavlov: A Biography. Chicago, University of Chicago Press, 1949.

19. Babkin BP. Secretorische und vasomotorische erscheinungen in der speicheldrusen. Pflugers Arch Gesamte Physiol Menschen Tiere 1913;149:497-520.

20. Babkin BP. Die Arbeit der Speicheldrusen beim Hunde nach Entfernung des Ganglion cervicale superior sympathici. Pflugers Arch Gesamte Physiol Menschen Tiere 1913;149:521-31.

21. Babkin BP. Die äussere Secretion der Verdaungsdrüsen. Berlin: Springer, 1912.

22. Bayliss W, Starling E. The mechanism of pancreatic secretion. J Physiol Lond 1902;28:325-52.

23. Modlin IM, Kidd M. Ernest Starling and the discovery of secretin. J Clin Gastroenterol 2001;32:187-92.

24. Modlin IM, Kidd M, Farhadi J. Bayliss and Starling and the nascence of endocrinology. Regul Pept 2000;93:109-23.

25. Babkin BP. The influence of insulin on the formation of glycogen. $\mathrm{Br}$ J Exp Pathol 1923;4:310-7.

26. Babkin BP, Starling EH. A method for the study of the perfused pancreas. J Physiol 1926;61:245-7.

27. Babkin BP. The influence of natural chemical stimuli on the movements of the alimentary canal. Can Med Assoc J 1925;15:719-24.

28. Babkin BP, Alley A, Stavraky GW. Humoral transmission of chorda tympany effect. Trans R Soc Can 1932;26:89-107. 
29. Feldberg W, Krayer O. Das Auftreten eines azetylcholinartigen Stoffes im Herzvenenblut von Warmblutern bei Reizung der Nervi vagi. Naunyn-Schmeidebergs Arch Exp Path Pharmak 1933;172:170-93.

30. Babkin BP. Antagonistic and synergistic phenomena in the autonomic nervous system. Trans R Soc Can 1946;40:1-25.

31. Babkin BP. The abnormal functioning of the gastric secretory mechanism as a possible factor in the pathogenesis of peptic ulcer. Can Med Assoc J 1938;38:421-9.

32. Soll AH. Potentiating interactions of gastric stimulants on [14 C] aminopyrine accumulation by isolated canine parietal cells. Gastroenterology 1982;83:216-23.

33. Sandor A, Kidd M, Lawton GP, Miu K, Tang LH, Modlin IM. Neurohormonal modulation of rat enterochromaffin-like cell histamine secretion. Gastroenterology 1996;110:1084-92.

34. Kidd M, Tang LH, Miu K, Lawton GP, Sandor A, Modlin IM. Autoregulation of enterochromaffin-like cell histamine secretion via the histamine 3 receptor subtype. Yale J Biol Med 1996;69:9-19.

35. Vineberg AM, Babkin BP. Histamine and pilocarpin in relation to the gastric secretion. Am J Physiol 1931;97:69-73.

36. Babkin BP. The value of histamine as a test of gastric secretion from a physiological point of view. Can Med Assoc J 1930;23:268-72.

37. Babkin BP. Testing of the secretory activity of the gastric glands by means of histamine and insulin. Am J Dig Dis 1939;5:753-4.

38. Babkin BP, Schachter M. The chemical phase of gastric secretion and the surgery of the stomach. Mcgill Med J 1944;18:127-38.

39. Babkin BP, Hebb CO, Sergejeva MA. The parasympathetic like effect of splanchnic nerve stimulation on pancreatic secretion. Q J Exp Biol 1939;217-37.

40. Babkin BP. Blood sugar concentration and the external secretion of the pancreas. J Am Med Assoc 1935;105:1659-62.

41. Babkin BP. The mechanism of the secretory activity of the digestive glands. Rev Can Biol 1943;2:416-34.

42. Edkins J. The chemical mechanism of gastric secretion. J Physiol 1906;34:133-44.

43. Edkins JS. On the chemical mechanism of gastric secretion. Proc R Soc Lond B Biol Sci 1905; 76:370-6.

44. Barger G, Dale $H$. The presence in ergot and physiological action of B-imidazolelylethylamine. J Physiol 1910;40:38-40.

45. Sacks J, Ivy AC, Burgess JP, Vandolah JE. Histamine as the hormone for gastric secretion. Am J Physiol 1932;101:331-8.

46. Schnedorf JG, Ivy AC. Failure of histamine and "Gastrin" to provoke gastric secretion in monkeys with anacidity. Proc Soc Exper Biol Med 1937;36:192-3.

47. Babkin BP. The "chemical" phase of gastric secretion and its regulation. Am J Dig Dis Nutr 1934;1:715-21.

48. Babkin BP. Modes of stimulation of the gastric secretion. Nature 1934;134:1005.

49. Friedman MH. Dr. S. A. Komarov: 1892-1964. Gastroenterology 1965;48:126-7.
50. Bralow SP. Special issue dedicated to S. A. Komarov. Am J Dig Dis 1966;11:73-89.

51. Komarov SA. Gastrin. Proc Soc Exp Biol Med 1938;38:514-6.

52. Komarov SA. Studies on gastrin. I. Method of isolation of a specific gastric secretagogue from the pyloric mucous membrane and its properties. Rev Can Biol 1942;1:191-205.

53. Komarov SA. Studies on gastrin. II. Physiological properties of the specific gastric secretagogue of the pyloric mucous membrane. Rev Can Biol 1942;1:377-401.

54. Babkin BP, Friedman MHF, MacKay-Sawyer ME. Vagal and sympathetic innervation of the snake. J Biol Bd Can 1934:1:239-50.

55. Babkin BP, Chaisson AF, Friedman MHF. Factors determining the course of the gastric secretion in Elasmobranchs. J Biol Bd Can 1934;1:251-9.

56. Beck IT. History of the first 30 years of the Canadian Association of Gastroenterology. Can J Gastroenterol 1992;6:345-64.

57. Babkin BP, Webster DR. The regulation of bile flow through the bile passages. Can Med Assoc J 1929;31:32-6.

58. Babkin BP, Armour JC, Webster DR. Restoration of the functional capacity of the stomach when deprived of its main arterial blood supply. Can Med Assoc J 1943;48:1-10.

59. Alvarez WC. Presentation of Friedenwald Medal to Dr PB Babkin. Gastroenterology 1949;13:77-9.

60. Gillmor D, Turgeon P. Canada, A People's History. Canadian Broadcasting Corporation, 2000.

61. Barer ML, Stoddard GL. Toward Integrated Medical Resource Policies for Canada. Report prepared for Federal/Provincial/Territorial Conference of Deputy Ministers of Health, 1991.

62. Romanow RJ. Building on Values. The Future of Health Care in Canada. Ottawa: Government of Canada, 2002.

63. Beck IT, Thomson M. The health care philosophy that nearly destroyed Medicare in Canada in a single decade. Clin Invest Med 2006. (In press)

64. Beck IT. Disproportion of economic impact, research achievements and research support in digestive diseases in Canada. Clin Invest Med 2001;24:12-36.

65. Beck IT, Depew WT. Canadian research fellowship training programs in digestive sciences: Achievements and challenges. Clin Invest Med 2001;24:44-53.

66. Tracy HJ, Gregory RA. Physiological properties of a series of synthetic peptides structurally related to gastrin I. Nature 1964;204:935-8.

67. Romano T, Li A. Celebrating the Medical Research Council of Canada. MR 21-19/2000, 1-24. 2000. Ottawa: Public Works and Government Services, 2000.

68. Fedorak RN. Economic impact of digestive, nutritional and oral diseases in Canada. Can J Gastroenterol 2000;14:13-4.

69. Fedorak RN. Canadian Institutes of Health Research: Should there be an institute for digestive sciences? Can J Gastroenterol 1999; 13:367-9. 


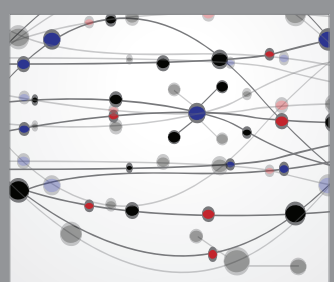

The Scientific World Journal
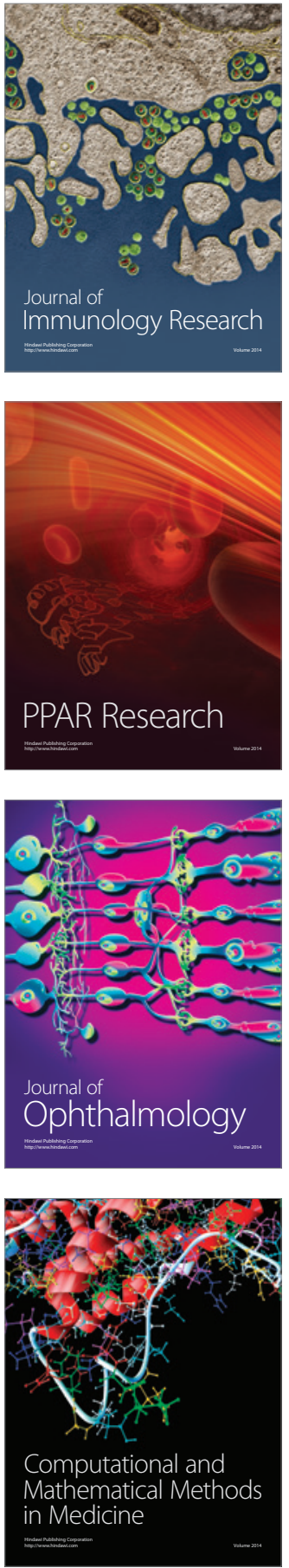

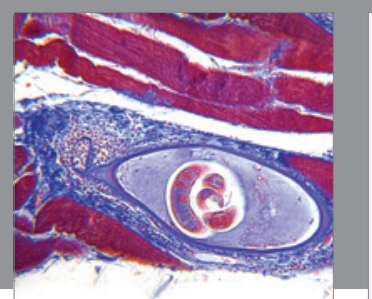

Gastroenterology Research and Practice

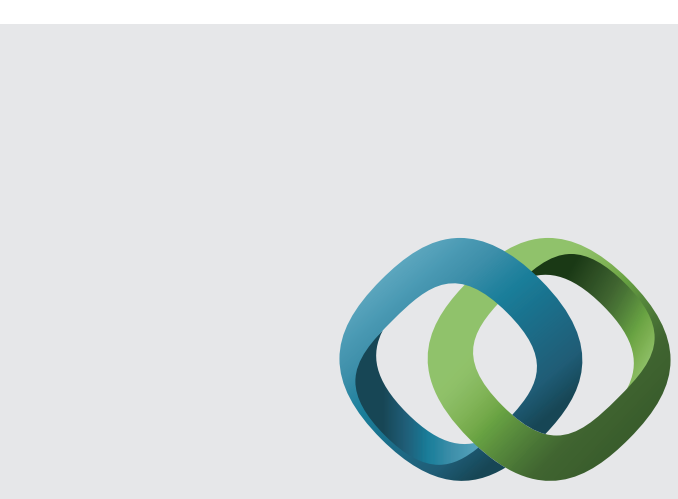

\section{Hindawi}

Submit your manuscripts at

http://www.hindawi.com
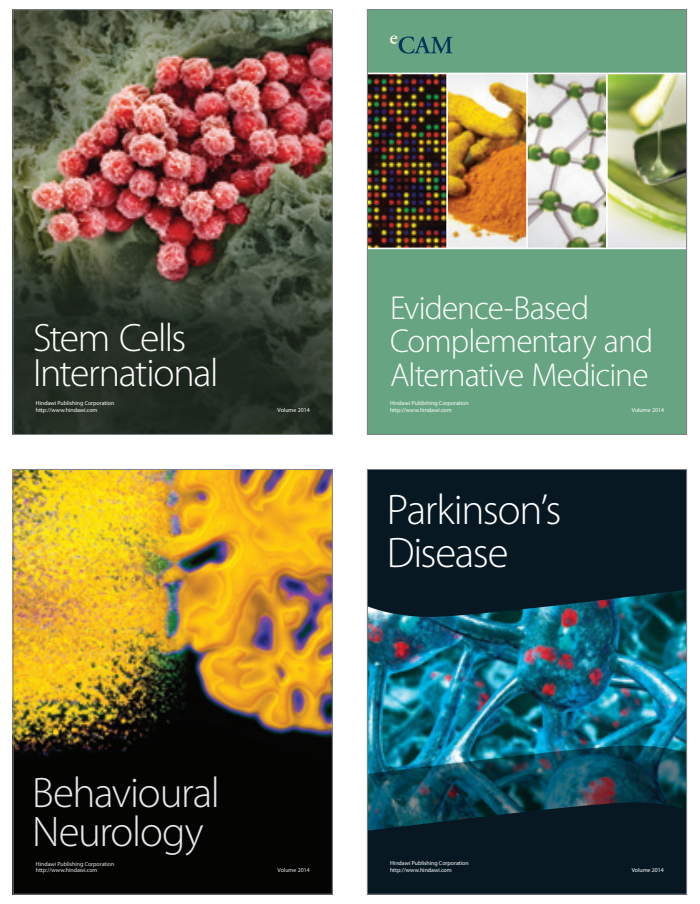
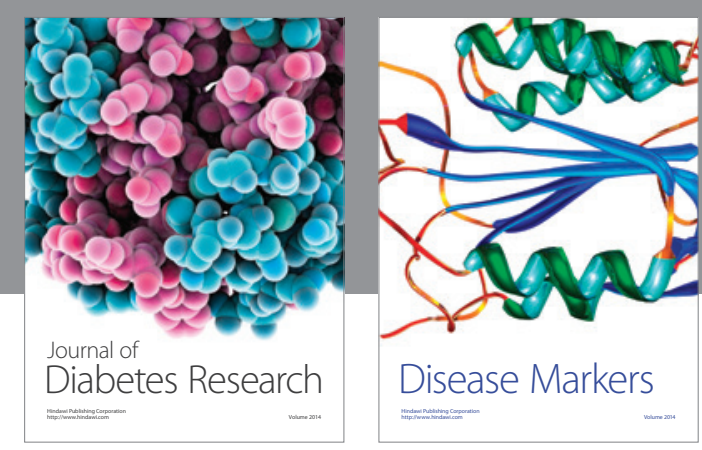

Disease Markers
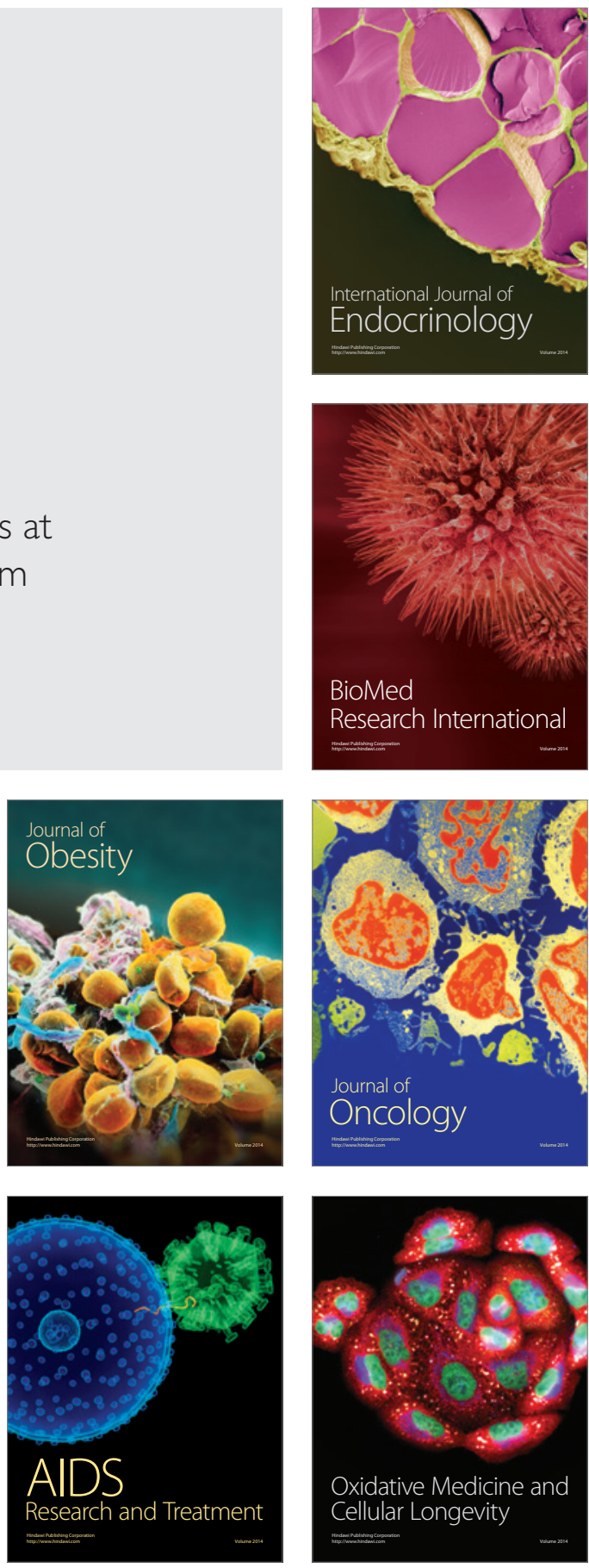